\title{
PENGARUH BERBAGAI SUHU PIROLISIS ASAP CAIR DARI CANGKANG SAWIT SEBAGAI BAHAN PENGGUMPAL LATEKS
}

\section{THE EFFECT OF VARIOUS PYROLISIS TEMPERATURE OF LIQUID SMOKE FROM PALM SHELLS AS LATEX COAGULANT}

\author{
Fauziati, Ageng Priatni, Yuni Adiningsih \\ Balai Riset Dan Standardisasi Industri Samarinda \\ Jl. MT Haryono / Bangeris No.1 Samarinda 75124 \\ Alamat Email : fauziati8@gmail.com
}

Diterima : 08-10-2018

Direvisi : 06-12-2018

Disetujui : 13-12-2018

\begin{abstract}
ABSTRAK
Cangkang kelapa sawit merupakah limbah padat sawit yang mempunyai kandungan senyawa aktif yang cukup potensial untuk dikembangkan menjadi produk lain seperti asap cair yang diperoleh dengan metoda pirolisis. Asap cair hasil pembakaran cangkang sawit pada proses pirolisis yang diperoleh sampai pada suhu $300{ }^{\circ} \mathrm{C}-400{ }^{\circ} \mathrm{C}$ merupakan asap cair yang terbaik yang dapat digunakan sebagai bahan penggumpal lateks. Tujuan penelitian adalah untuk mengetahui pengaruh suhu pembakaran cangkang sawit yang optimal melalui proses pirolisis, sehingga dihasilkan asap cair yang dapat digunakan sebagai bahan penggumpal lateks. Metoda penelitian yang digunakan adalah secara batch dan dilakukan pengamatan untuk masing-masing interval suhu pirolisis yaitu suhu $23^{\circ} \mathrm{C}-100^{\circ} \mathrm{C}, 100^{\circ} \mathrm{C}$ - $200{ }^{\circ} \mathrm{C}, 200{ }^{\circ} \mathrm{C}-300{ }^{\circ} \mathrm{C}$ dan $300{ }^{\circ} \mathrm{C}-400{ }^{\circ} \mathrm{C}$ terhadap parameter waktu, volume, pH, BJ, kadar air, kadar asam asetat, senyawa aktif dan daya hambat bakteri. Pada penggumpalan lateks, digunakan asap cair hasil pirolisis pada kisaran suhu $300-400{ }^{\circ} \mathrm{C}$ dengan konsentrasi variasi $2 \%, 6 \%, 10 \%$ dan $14 \%$ serta larutan TSP $2 \%$, sementara sebagai kontrol digunakan asam formiat $2 \%$. Asap cair hasil pembakaran secara pirolisis pada suhu $300-400{ }^{\circ} \mathrm{C}$ menghasilkan senyawa aktif yang mempunyai peranan sebagai bahan penggumpal lateks yaitu senyawa asam asetat, senyawa phenol dan $\mathrm{pH}$ rendah sebagai bahan anti bakteri dan jamur pada lateks. Pada suhu tersebut dihasilkan anti bakteri/ anti jamur yaitu E. Colli, Staphilococus aureus dan Salmonella dengan kategori kuat dan sangat kuat. Kelebihan asap cair dibandingkan dengan asam formiat yang digunakan sebagai penggumpal lateks adalah disamping senyawa asam asetat juga mengandung senyawa fenol yang berpengaruh terhadap $\mathrm{pH}$ dan anti jamur / bakteri, sedangkan asam formiat hanya memberikan $\mathrm{pH}$ rendah dan waktu penggumpalan lateks yang cepat.
\end{abstract}

Kata Kunci : asap cair, asam asetat, cangkang sawit, penggumpal lateks, suhu pembakaran

\section{ABSTRACT}

Palm oil shells are palm oil solid wastes which contain active compounds that are potential enough to be developed into other products such as liquid smoke obtained by the pyrolysis method. Liquid smoke from burning palm kernel shells in the pyrolysis process obtained at temperatures of $300^{\circ} \mathrm{C}-400^{\circ} \mathrm{C}$ is the best liquid smoke that can be used as a latex clumping material. The aim of the study was to determine the effect of optimal oil palm shell combustion temperature through the pyrolysis process, so that liquid smoke can be produced which can be used as a latex clumping material. The research method used was batch and observed for each pyrolysis temperature interval, $23^{\circ} \mathrm{C}-100^{\circ} \mathrm{C}, 100^{\circ} \mathrm{C}$ $200^{\circ} \mathrm{C}, 200^{\circ} \mathrm{C}-300^{\circ} \mathrm{C}$ and $300^{\circ} \mathrm{C}-400^{\circ} \mathrm{C}$ for the parameters of time, volume, $\mathrm{pH}, \mathrm{BJ}$, water content, acetic acid levels, active compounds and bacterial inhibition. In the latex clumping, liquid pyrolysis smoke was used at a temperature range of $300-400^{\circ} \mathrm{C}$ with concentration variations: $2 \%, 6 \%$, $10 \%$ and $14 \%$ and $2 \%$ TSP solution, while formic acid was used $2 \%$. The liquid smoke from combustion by pyrolysis at a temperature of $300-400^{\circ} \mathrm{C}$ produces an active compound which has a role as a latex clumping agent, name acetic acid compounds, phenol compounds and low pH as anti - bacteria / anti 
fungi such as E. Colli, Staphilococus aureus and Salmonella with strong and very strong category. Excessed liquid smoke, if compared to formic acid used as coagulation of latex are in addition to the compounds of acetic acid also contain phenol compounds which have an effected pH and anti - fungi I anti bacteria, while formic acid only provides a low pH and fast latex clotting time.

Keywords : liquid smoke, acetic acid, palm shell, latex clump, combustion temperature

\section{PENDAHULUAN}

elapa sawit dengan kapasitas 100 ribu ton tandan buah segar (TBS) pertahun menghasilkan sekitar 6 (enam) ribu ton cangkang sawit, 12 (dua belas) ribu ton serabut dan 23 (Dua puluh tiga) ton tandan buah kosong (Marpaung, 2009)., dari Produksi TBS (Tandan Buah Segar) sebesar 11.418.110 ton pada tahun 2016 yang dihasilkan di Kalimantan Timur akan dihasilkan cangkang kelapa sawit sekitar \pm 268.293 ton (Dinas Perkebunan Prov. Kaltim, 2014). Sehingga cukup potensial bila cangkang sawit dikembangkan sebagai bahan baku industri. Menurut Pranata dalam Gani, dkk (2009), cangkang kelapa sawit mengandung lignin $(29,4 \%)$, hemiselulose $(27,7 \%)$, sellulose $(26,6 \%)$, Air $(8,0 \%)$,komponen ekstraktif $(4,2$ $\%)$ dan abu $(0,6 \%)$. Limbah ini sangat berpotensi jika dikembangkan menjadi produk produk yang bermanfaat dan memberi nilai tambah dari aspek ekonomi serta ramah lingkungan seperti asap cair, bahan bakar, briket dan lain - lain.

Komposisi utama yang terdapat dalam cangkang kelapa sawit adalah hemiselulosa, selulosa dan lignin. Hemiselulosa terdiri dari pentosan $\left(\mathrm{C}_{5} \mathrm{H}_{8} \mathrm{O}_{4}\right)$ dan heksosan $\left(\mathrm{C}_{6} \mathrm{H}_{10} \mathrm{O}_{5}\right)$. Pentosan mengalami pirolisis menghasilkan furfural, furan, dan turunannya serta asam karboksilat. Hasil pirolisis selulosa yang terpenting adalah asam asetat dan fenol dalam jumlah yang sedikit. Sedangkan pirolisis lignin menghasilkan aroma yang berperan dalam produk pengasapan. Senyawa aroma yang dimaksud adalah fenol dan eterfenolik seperti guaiakol (2 metoksi fenol), siringol (1,6 - dimetoksi fenol) dan derivatnya (Girard, 1992).

\section{Metode Pirolisis}

Pirolisis merupakan proses pemanasan suatu zat tanpa adanya oksigen sehingga terjadi penguraian komponen - komponen senyawa kimia . Proses pirolisis pada cangkang kelapa sawit seperti selulosa, hemiselulosa dan lignin menghasilkan zat atau senyawa dalam tiga bentuk yaitu padatan berupa karbon, cairan (asap cair, tar) dan gas yang tidak terkondensasi (D. Tilman, 1981; I. Tahir 1992).

Menurut Darmadji (2010) bahwa asap cair cangkang kelapa sawit hasil pirolisis sebelum dilakukan proses pemurnian mempunyai bau yang khas menyengat dan warna dari kuning kecoklatan sampai hitam, mempunyai daya hambat terhadap bakteri yang kuat karena mengandung senyawa asam karboksilat seperti asam asetat merupakan hasil pirolisis dari selulose, dan phenol sebagai anti oksidan merupakan hasil pyrolisis dari lignin dan karbonil hasil pirolisis dari hemiselulose. Pirolisis menggunakan bahan cangkang kelapa sawit telah menghasilkan senyawa aktif dengan kadar yang bervariasi tergantung dari suhu dan waktu pirolisis yang digunakan dan menghasilkan asap cair dengan volume yang bervariasi. Berdasarkan hukum kimia fisika, apabila suhu, tekanan dirubah maka volume akan berubah.

Pada proses pembakaran bahan baku didalam pirolisis, tumpukan cangkang sawit didalam tabung pirolisis hanya dapat mengisi setengah bagian tabung . Hal ini dilakukan agar semua cangkang sawit didalam tabung pirolisis dapat terbakar dengan baik karena proses pembakaran terjadi secara tidak langsung. Setelah 15 - 20 menit proses pembakaran berlangsung, asap akan mengalir melalui pipa penyalur asap dan akan mengalir menuju pipa kondensor dengan air mengalir pada tabung kondensor yang akan mendinginkan asap sehingga dihasilkan asap berupa cairan dan dihasilkan asap cair. Proses akan berakhir bila alat pirolisis tidak mengeluarkan asap cair lagi , dengan membutuhkan waktu rata - rata 3-4 jam. Asap cair yang dihasilkan masih bercampur dengan tar dalam konsentrasi yang tinggi dan 
berwarna hitam. Sehingga masih perlu dilakukan pemurnian dengan cara didiamkan selama satu minggu kemudian disaring untuk bahan penggumpal lateks.

\section{Asap Cair}

Asap diperoleh melalui pembakaran bahan yang banyak mengandung selulosa, hemiselulosa dan lignin. Pembakaran hemiselulosa, selolusa, dan lignin akan menghasilkan senyawa asam dan turunannya dan fenol. Selain kayu juga dapat digunakan tempurung dan sabut kelapa, sampah organik, cangkang kopi, cangkang kelapa sawit bambu maupun merang padi sebagai penghasil asap cair (Sutin, 2008).

Pada proses pembuatan asap cair dihasilkan 3 (tiga ) jenis asap cair yaiu asap cair grade 1 , asap cair grade 2 dan asap cair grade 3 . Untuk asap cair grade 1 difungsikan sebagai bahan pengawet makanan, asap cair grade 2 dikondisikan sebagai bahan pengawet bahan -bahan makanan dan asap cair grade 3 adalah asap cair yang tidak melalui proses pemurnian hanya pengendapan selama 1 minggu dan setelah itu dilakukan penyaringan biasanya digunakan sebagai bahan penggumpal lateks, pupuk dan desenfektan.

Asap cair dapat diproduksi dengan metode destilasi kering (pirolisis) dari bahan kayu atau tempurung pada suhu $400^{\circ} \mathrm{C}$. Untuk memperoleh asap cair dapat dilakukan proses pirolisis bahan yang mengandung hemiselulosa pada suhu 220 - $400{ }^{\circ} \mathrm{C}$, selulosa pada suhu 320 $420^{\circ} \mathrm{C}$, dan lignin pada suhu di atas $400^{\circ} \mathrm{C}$ (Venderbosch and Prins, 2010).

Asap cair dari cangkang kelapa sawit, mengandung senyawa kimia diantaranya asam asetat, asam etanoat, asam glasial, asam format, etil eter, etil format, etil metanoat, etil formiat, formik eter, asam propaoat, asam prapionik, karbohidrat, fenol, benzenol, monofenol, eksibenzen, asam benzensulfonat 4 - hidroksi, dan benzensulfonat parahidroksi. Produk yang diberi perlakuan asap yang diproduksi pada suhu $400^{\circ} \mathrm{C}$ lebih unggul dalam mutu organoleptiknya terhadap produk yang diberi perlakuan asap pada suhu yang lebih tinggi (Girard, 1992).

Menurut Ratnawati dan Singgih (2010) bahwa peningkatan temperatur sebesar $150^{\circ} \mathrm{C}$ (dari $350-500^{\circ} \mathrm{C}$ ), secara nyata tidak merubah komposisi kondensat asap tetapi terjadi sedikit peningkatan efek antioksidatif dan tidak berpengaruh pada efek antimikrobianya, sehingga menyimpulkan bahwa temperatur optimum untuk pembuatan asap berkisar $400^{\circ} \mathrm{C}$. Senyawa penyusun asap cair dapat dipisahkan berdasarkan titik didihnya. Titik didih senyawa senyawa pendukung sifat fungsional asap cair dalam keadaan murni dapat dilihat pada Tabel 1.

Tabel 1. Senyawa Penyusun Asap Cair Berdasarkan Titik didihnya

\begin{tabular}{ll}
\hline \multicolumn{1}{c}{ Senyawa } & $\begin{array}{c}\text { Titik Didih } \\
\left({ }^{\circ} \mathrm{C}, 760 \mathrm{mmHg}\right)\end{array}$ \\
\hline Fenol & \\
\hline Guaiakol & 205 \\
\hline 4 - metilguaikol & 211 \\
\hline Eugenol & 244 \\
\hline Siringol & 267 \\
\hline Furfural & 162 \\
\hline Piroketakol & 240 \\
\hline Hidroquinon & 285 \\
\hline Isoeugenol & 266 \\
\hline Karbonil & \\
\hline Glioksal & 57 \\
\hline Metil glioksal & 72 \\
\hline
\end{tabular}




\begin{tabular}{ll}
\hline Glioksal dehida & 97 \\
\hline Diasetil & 88 \\
\hline Formaldehida & 21 \\
\hline Asam & \\
\hline Asam asetat & 118 \\
\hline Asam butirat & 162 \\
\hline Asam propionate & 141 \\
\hline Asam isovalerat & 176 \\
\hline
\end{tabular}

\section{Koagulant Lateks}

Koagulasi adalah peristiwa penggumpalan suatu sistem koloid, dimana sifat koloid yang ada pada lateks dijadikan sebagai dasar terjadinya proses koagulasi atau penggumpalan. Tujuan dari koagulasi adalah menyatukan butir - butir karet yang terdapat dalam cairan. lateks agar terjadi gumpalan atau koagulum. Terjadinya perubahan lateks menjadi koagulum memerlukan bahan pembeku seperti asam semut atau asam cuka .Lateks segar mempunyai $\mathrm{pH}$ sebesar 6,5, sedangkan $\mathrm{pH}$ yang diperlukan untuk mengubah lateks menjadi koagulum adalah $\mathrm{pH} \pm 4,7$ (Taher et al, 2012). Pada saat ini dipetani karet menggunakan bahan penggumpal lateks asam formiat ( asam semut) dengan $\mathrm{pH}$ yang sangat rendah sekitar \pm 2,0 sehingga dalam pemanfaatannya sebagai penggumpal lateks perlu diencerkan lagi . Asam formiat atau asam semut adalah senyawa kimia yg hanya mengandung senyawa karboksilat saja, sedangkan asap cair mengandung senyawa phenol dan senyawa lain yg dapat digunakan sebagai senyawa anti oksidan dan hasil produksi lateks dengan menggunakan penggumpal lateks dari asam formiat akan menghasilkan limbah industri yang sangat mencemari lingkungan .

Senyawa fenol berperan sebagai antioksidan sehingga dapat memperpanjang masa simpan produk asapan. (Ratna, 2008). Menurut Daun (1979), Maga (1987) menyatakan fenol dengan titik didih yang lebih tinggi akan menunjukkan sifat antioksidan yang lebih baik jika dibandingkan dengan senyawa fenol yang bertitik didih rendah karena fenol dengan titik didih tinggi dalam asap juga merupakan zat antibakteri yang tinggi. Kadar fenol bervariasi tergantung pada bahan yg dibakar dengan rata - ratanya 2,85\% untuk kayu , sedangkan untuk tempurung kelapa sebesar 5,13\% (Tranggono dkk, 1997) . Maga, 1987).

Tujuan penelitian adalah untuk mengetahui pengaruh suhu pembakaran cangkang sawit yang optimal melalui proses pirolisis, sehingga dihasilkan asap cair yang dapat digunakan sebagai bahan penggumpal latekssintesis asap cair dari cangkang kelapa sawit dengan teknologi pirolisis sebagai koagulan lateks.

\section{METODE PENELITIAN \\ Bahan dan Alat}

Bahan yang digunakan cangkang sawit, kertas saring, bahan analisa daya hambat bakteri, koagulasi lateks larutan asam semut 2\% ( dari petani ) ,larutan TSP 2\% (dari petani ) dan peralatan yang digunakan adalah 1 set alat pirolisis, glassware, corong gelas.

\section{Metode :}

Proses pirolisis yang dilakukan secara batch, dilakukan pengamatan untuk masing masing interval suhu pirolisis yaitu suhu $23^{\circ} \mathrm{C}-100^{\circ} \mathrm{C}, 100^{\circ} \mathrm{C}-200^{\circ} \mathrm{C}, 200^{\circ} \mathrm{C}-300^{\circ} \mathrm{C}$ dan $300^{\circ} \mathrm{C}-400^{\circ} \mathrm{C}$ terhadap parameter waktu pirolis , volume , $\mathrm{pH}$,Berat Jenis (BJ),kadar air,kadar asam asetat, senyawa aktif dan daya hambat bakteri .

Pada penggumpalan lateks, digunakan asap cair hasil pirolisis pada kisaran suhu 300 - $400{ }^{\circ} \mathrm{C}$ dengan konsentrasi variasi : $2 \%, 6 \%, 10 \%$ dan $14 \%$ serta larutan TSP $2 \%$, sementara sebagai kontrol digunakan asam formiat $2 \%$. 


\section{Prosedur :}

\section{Proses Pembuatan Asap Cair dari Cangkang Sawit}

Cangkang sawit dibersihkan dari kernel, serabut dan kotoran lain. Kemudian sebanyak 35 $\mathrm{kg}$ cangkang sawit kering dibakar dengan metode pirolisis sampai dengan suhu $400{ }^{\circ} \mathrm{C}$. Asap yang diperoleh kemudian dialirkan ke dalam destilator dan dikondensasikan. Kondensat yang dihasilkan kemudian diendapkan selama 1 minggu dan disaring untuk menghilangkan senyawa - senyawa yang tidak diinginkan. Asap cair yang diperoleh kemudian dihitung volumenya, begitu juga dengan berat arang cangkang sawit sisa pembakaran dan lama waktu pirolisis. Kemudian menghitung rendemen asap cair dan arang cangkang sawit. Selama proses pirolisis secara batch dilakukan pula pengamatan terhadap senyawa - senyawa aktif asap cair pada interval suhu $23{ }^{\circ} \mathrm{C}-100{ }^{\circ} \mathrm{C}, 100{ }^{\circ} \mathrm{C}-200{ }^{\circ} \mathrm{C}, 200-300{ }^{\circ} \mathrm{C}$ dan $300{ }^{\circ} \mathrm{C}-400{ }^{\circ} \mathrm{C}$ dan sifat fisik - kimia yaitu $\mathrm{pH}, \mathrm{BJ}$, kadar air dan kadar asam asetat.Semua perlakuan di atas diulang sebanyak 3 kali.

Gambar alat pirolisis sebagaimana Gambar 1 dibawah ini :

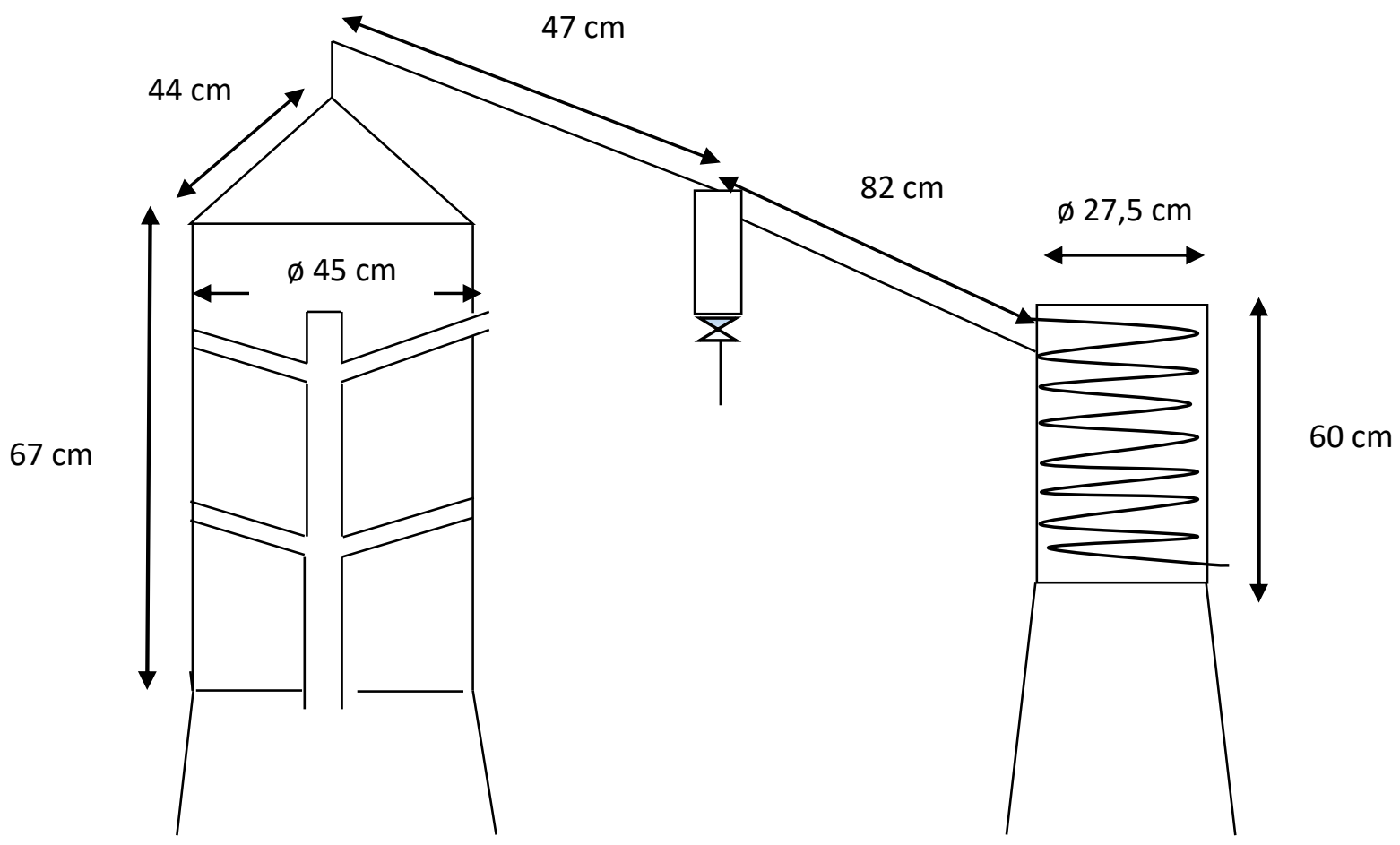

Gambar 1. Alat pirolisis cangkang sawit

\section{Aplikasi Koagulan Lateks}

Lateks segar masing - masing sebanyak $100 \mathrm{ml}$ (ditimbang beratnya untuk menghitung rendemen/A) diencerkan dengan $100 \mathrm{ml}$ aquadest (hitung beratnya/B) yang kemudian dimasukkan ke dalam wadah atau nampan yang berukuran $14 \mathrm{~cm} \times 7 \times 3 \mathrm{~cm}$, selanjutnya digumpalkan dengan $15 \mathrm{ml}$ asap cair cangkang sawit dengan konsentrasi $2 \%, 6 \%, 10 \%, 14$ $\%$, larutan asam formiat $2 \%$ dan larutan TSP $2 \%$. Penambahan asap cair ke dalam campuran lateks segar dan aquadest dilakukan secara perlahan sambil diaduk hingga terbentuk koagulum yang sempurna, ditandai dengan jernihnya warna serum. Kemudian dicatat lamanya proses penggumpalan. Lateks yang sudah menggumpal kemudian dikeluarkan dari nampan dan ditimbang $(\mathrm{C})$. Selanjutnya menghitung rendemen dengan rumus : 
Rendemen $=\frac{C}{(A+B)} \times 100 \%$

\section{HASIL DAN PEMBAHASAN}

Pada penelitian ini dibahas tentang hasil asap cair sebagai fungsi variasi temperatur. Adapun variasi temperatur yang dilakukan adalah dengan kisaran suhu $23^{\circ} \mathrm{C}-100{ }^{\circ} \mathrm{C}, 100$ ${ }^{\circ} \mathrm{C}-200{ }^{\circ} \mathrm{C}, 200^{\circ} \mathrm{C}-300^{\circ} \mathrm{C}$ dan $300{ }^{\circ} \mathrm{C}-400{ }^{\circ} \mathrm{C}$. Hasil analisa asap cair yang dihasilkan sebagai fungsi dari variasi temperatur adalah waktu pirolisis, volume asap cair yang dihasilkan , $\mathrm{pH}$ asap cair, Berat Jenis asap cair dan asam asetat yang dihasilkan dari proses pirolisis asap cair.

Tabel 2. Hasil Analisa Asap Cair sebagai Fungsi Variasi Temperatur

\begin{tabular}{cccccc} 
Suhu ( & $\begin{array}{c}\text { Waktu } \\
(\text { menit})\end{array}$ & $\begin{array}{c}\text { Volume } \\
(\mathrm{ml})\end{array}$ & $\mathrm{pH}$ & $\begin{array}{c}\mathrm{B} J \\
(\mathrm{~g} / \mathrm{ml})\end{array}$ & $\begin{array}{c}\text { Kadar Asam } \\
\text { Asetat }(\%)\end{array}$ \\
\hline $23-100$ & 29,96 & 1650,00 & 3,2 & 0,98 & 2,0 \\
\hline $100-200$ & 49,67 & 2113,33 & 3,0 & 0,98 & 6,0 \\
\hline $200-300$ & 60,67 & 2320,00 & 2,9 & 0,99 & 13.5 \\
\hline $300-400$ & 82,00 & 2776,67 & 2,8 & 1,00 & 15,0 \\
\hline $\begin{array}{c}\text { Jumlah/ } \\
\text { Rata - rata }\end{array}$ & 219,3 & 8.860 & 2,83 & 0,99 & 39,5 \\
\hline
\end{tabular}

Tabel 2. menunjukkan bahwa volume asap cair yang dihasilkan pada suhu pirolisis 23 ${ }^{\circ} \mathrm{C}-100{ }^{\circ} \mathrm{C}$ sebesar 1.650 liter, suhu pirolisis $100-200^{\circ} \mathrm{C}$ sebesar $2113,33 \mathrm{ml}$, suhu $200-300$ ${ }^{\circ} \mathrm{C}$ sebesar $2320,00 \mathrm{ml}$ dan suhu pirolisis $300-400{ }^{\circ} \mathrm{C}$ sebesar $2776,67 \mathrm{ml}$ sehingga volume keseluruhan asap cair yg dihasilkan sebesar $8.860 \mathrm{ml}$ ( 8,86 Lt). Hal ini menunjukkan bahwa semakin tinggi suhu pirolisis maka jumlah asap cair yang dihasilkan semakin banyak, yang disebabkan karena semakin tinggi suhu maka kecepatan reaksi pirolisis akan semakin meningkat sehingga kemampuan untuk menguraikan senyawa - senyawa organik yang ada pada cangkang kelapa sawit juga semakin besar, sesuai dengan pendapat Ramakhrisnan dan Moeller (2002) yang menyatakan bahwa nilai jumlah asap cair sangat bergantung pada suhu, laju pemanasan, ukuran partikel, jenis dan komposisi dari bahan baku.Lima (5) senyawa utama yang teridentifikasi yaitu asam asetat rata - rata $39,50 \%$, dengan pengaruh suhu pirolisis dihasilkan asam asetat dari $23-100^{\circ} \mathrm{C}$ sebesar $2,0 \%$, suhu $100-200^{\circ} \mathrm{C}$ sebesar $6,0 \%$ , $200-300^{\circ} \mathrm{C}$ sebesar $13,50 \%$ dan suhu $300-400^{\circ} \mathrm{C}$ sebesar $15,0 \%$ sehingga jumlah asam asetat yang dihasilkan sebesar $39,50 \%$. Hasil ini menunjukkan bahwa semakin tinggi suhu pirolisis maka kadar asam asetat asap cair yang dihasilkan semakin besar.

Pengamatan terhadap waktu pirolisis terkait suhu ,dimana semakin tinggi suhu pirolisis maka diperoleh waktu pirolisis semakin lama sesuai dengan pendapat dari Ginayati dkk (2015) semakin tinggi suhu pirolisis maka semakin lama waktu yang dibutuhkan untuk mencapai temperatur tersebut Pada kisaran suhu $23^{\circ} \mathrm{C}-100{ }^{\circ} \mathrm{C}, \mathrm{pH}$ yang dihasilkan sebesar 3,2 dan pada kisaran suhu $300^{\circ} \mathrm{C}-400^{\circ} \mathrm{C}$ diperoleh $\mathrm{pH}$ asap cair sebesar 2,8 . Hal ini menunjukkan bahwa semakin tinggi suhu pirolisis maka jumlah asam asetat ( asam karboksilat ) yang dihasilkan semakin besar sebagaimana ditunjukkan pada tabel 2.Kenaikan kadar asam asetat juga berbanding lurus dengan penurunan nilai $\mathrm{pH}$. ( rata - rata nilai $\mathrm{pH} 2,83$ ). Pada kisaran suhu pirolisis $23-100{ }^{\circ} \mathrm{C}$ diperoleh berat jenis asap cair sebesar $0,98 \mathrm{~g} / \mathrm{ml}$ dan pada suhu pirolisis $300-400{ }^{\circ} \mathrm{C}$ diperoleh berat jenis asap cair sebesar 1,00. Hasil ini menunjukkan bahwa semakin tinggi suhu pirolisis maka berat jenis asap cair yang dihasilkan semakin besar, hal ini disebabkan karena jumlah dan jenis senyawa yang dihasilkan juga 
berbeda - beda sebagaimana tabel 3. Menurut Bloomfield (1983), pada suhu senyawa yang tinggi serta volume suatu bahan dapat mempengaruhi berat jenisnya.

Kadar asam asetat menyatakan banyaknya jumlah senyawa asam asetat yang terkandung di dalam asap cair. Pada Tabel 2 diperoleh hasil bahwa pada kisaran suhu pirolisis $23-100{ }^{\circ} \mathrm{C}$ diperoleh kadar asam asetat sebesar $2 \%$, suhu $100-200{ }^{\circ} \mathrm{C}$ diperoleh asam asetat sebesar dan pada suhu pirolisis 300 - $400{ }^{\circ} \mathrm{C}$ diperoleh kadar asam asetat sebesar $15 \%$. Pada tabel 3 menunjukkan bahwa \% area asam asetat yang dihasilkan oleh masing - masing suhu pirolisis secara berturut - turut adalah 24,04 \%, 43,87 \%, 47, $43 \%$ dan 50,54 \%.

Tabel 3. Hasil Analisa GC MS Senyawa Aktif Asap Cair CangkangSawit Pada Berbagai Suhu

\begin{tabular}{ccc} 
& $\%$ Area & Rata \\
\cline { 2 - 3 } Senyawa aktif & rata \\
\hline
\end{tabular}

\begin{tabular}{cccccc} 
Ethylene Glyco & 32,73 & 19,30 & 8,33 & 4,78 & 16,29 \\
\hline Asam asetat & 24,04 & 43,87 & 47,43 & 50,54 & 41,47 \\
\hline Aceton & 12,59 & 6,95 & 2,39 & 2,15 & 6,02 \\
\hline Furfural & 10,44 & 6,94 & 2,47 & 2,15 & 5,50 \\
\hline Phenol & 10,24 & 21,11 & 30,79 & 32,59 & 23,68 \\
\hline Butanon & 0,80 & 0,38 & 0,22 & 0,18 & 0,34 \\
\hline $\begin{array}{c}\text { Asam } \\
\text { Propionat }\end{array}$ & - & 1,29 & 1,34 & 1,41 & 1,35 \\
\hline Etanol & - & - & - & 2,23 & 2,23 \\
\hline Lain - lain & 9,16 & 0,16 & 7,03 & 0,12 & 3,12 \\
\hline
\end{tabular}

Asap cair yang dihasilkan tersebut adalah asap cair grade 3 yaitu tanpa perlakuan pemurnian hanya dengan penyaringan yang biasanya digunakan sebagai bahan penggumpal lateks dan pupuk. Pada tabel 3 menunjukkan bahwa semakin tinggi suhu pirolisis, maka semakin rendah $\mathrm{pH}$ asap cair yang dihasilkan. Pada kisaran suhu $300-400{ }^{\circ} \mathrm{C} \mathrm{pH}$ yang dihasilkan sebesar 2,8 dan kadar asam asetat dan fenol yang dihasilkan juga semakin besar. Senyawa fenol sebesar 32,59\% area dan asam asetat yang dihasilkan adalah sebesar $50,54 \%$ area .Semakin besar suhu maka semakin besar kandungan asam asetat dan phenol yang dihasilkan , karena cangkang sawit yang mengandung selulose , hemisilulose dan lignin pada proses pirolisis akan mengalami degradasi yaitu lignin akan tergdegradasi menjadi fenol dan hemiselulose terdegradasi menjadi asam asetat hal ini berpangaruh terhadap $\mathrm{pH}$ semakin rendah yang akhirnya akan berpengaruh terhadap daya hambat pertumbuhan bakteri seperti yang ditunjukkan pada ( tabel 4 ) diperlukan dalam penggumpalan lateks karena akan menghasilkan kualitas lateks yang baik. Hal ini sesuai dengan pendapat Tranggono et al (1997), bahwa kandungan maksimum senyawa - senyawa fenol , karbonil dan asam dicapai pada suhu $400{ }^{\circ} \mathrm{C}-600{ }^{\circ} \mathrm{C}$, sedangkan menurut Darmadji et al ,(1999) , kandungan maksimum senyawa - senyawa fenol ,karbonil dan asam dicapai pada temperatur $600{ }^{\circ} \mathrm{C}$. Tetapi produk yang dihasilkan untuk asap cair pada suhu $400{ }^{\circ} \mathrm{C}$ dinilai mempunyai kualitas organoleptik yang terbaik dibandingkan dengan asap cair yang dihasilkan pada temperatur yang lebih tinggi. 
Hasil analisa daya hambat terhadap bakteri Escheria coli, Staphylococus aureus dan Salmonella $s p$ dengan menggunakan asap cair dari berbagai suhu dapat dilihat pada tabel 4 berikut ini.

Tabel 4. Hasil Analisa Daya Hambat Pada bakteri E.coli, Staphilococcus aureus dan Salmonella sp

\begin{tabular}{cccc}
\hline Suhu Pyrolisis & $\begin{array}{c}\text { Escheria } \\
\text { coli Zona } \\
\text { diameter } \\
\mathrm{mm})\end{array}$ & $\begin{array}{c}\text { Staphylococ } \\
\text { us aureus } \\
\text { zona } \\
\text { diameter } \\
(\mathrm{mm})\end{array}$ & $\begin{array}{c}\text { Salmonella } s p \\
\text { Zona diameter } \\
(\mathrm{mm})\end{array}$ \\
\hline $23-100^{\circ} \mathrm{C}$ & 7 & 9 & 6 \\
\hline $100-200^{\circ} \mathrm{C}$ & 6,5 & 16 & 12 \\
\hline $200-300^{\circ} \mathrm{C}$ & 12,5 & 23 & 20 \\
\hline $300-400^{\circ} \mathrm{C}$ & 13,5 & 25 & 22 \\
\hline
\end{tabular}

Berdasarkan hasil analisa daya hambat terhadap pertumbuhan bakteri Escheria Colli, Stapylococus aureus dan Salmonella sp ( tabel 4) adalah semakin tinggi temperatur semakin besar daya hambat terhadap pertumbuhan bakterinya . Sesuai dengan pernyataan Herwig (1979) dalam Rahmi ,N (2008) dan Titik Pudjilestari (2010) bahwa suatu bahan memiliki daya hambat pertumbuhan bakteri sangat kuat bila diameter hambatnya $>20 \mathrm{~mm}$, kuat 10 - $20 \mathrm{~mm}$, sedang $5-10 \mathrm{~mm}$ dan lemah $<5 \mathrm{~mm}$.

Dari hasil analisa daya hambat terhadap pertumbuhan bakteri pada kisaran suhu pyrolisis $23^{\circ} \mathrm{C}-100^{\circ} \mathrm{C}$ sampai dengan $300^{\circ} \mathrm{C}-400^{\circ} \mathrm{C}$ untuk Staphylococus aureus dan Salmonella Sp dari sedang sampai sangat kuat, sedangkan untuk bakteriEscheria colli dari sedang sampai dengan kuat. Hal tersebut sesuai dengan kandungan senyawa asam asetat dan fenol yang terdapat dalam asap cair dengan suhu pyrolisis nya, semakin tinggi suhu pyrolisis semakin tinggi senyawa asam asetat, fenol dan $\mathrm{pH}$ semakin rendah yang mempunyai peranan terhadap anti bakteri semakin kuat. Dalam hal ini asap cair yang digunakan sebagai bahan penggumpal lateks semakin maksimal disamping terjadinya penggumpalan lateks juga akan tejadi gumpalan lateks yang bebas dari bakteri ,hal ini disebakan karena bahan penggumpal lateks asap cair tidak hanya mengandung asam juga terdapat fenol dan senyawa lain sebagai bahan anti oksidan sehingga terjadinya proses anti bakteri yang lebih besar. Dimana untuk bahan penggumpal lateks yang biasa digunakan petani adalah asam formiat murni, tidak ada kandungan fenoldan senyawa lainnya yang berperan terhadap anti bakteri.

\section{Aplikasi Koagulasi Lateks}

Asap cair yang diperoleh pada kisaran suhu $300-400{ }^{\circ} \mathrm{C}$ merupakan asap cair yang terbaik yang dapat digunakan sebagai bahan penggumpal lateks. Pada penggumpalan lateks, digunakan asap cair hasil pirolisis pada kisaran suhu $300-400{ }^{\circ} \mathrm{C}$ dengan konsentrasi yang bervariasi yaitu $2 \%, 6 \%, 10 \%$ dan $14 \%$ serta larutan TSP $2 \%$, sementara sebagai kontrol digunakan asam formiat $2 \%$. Adapun karakteristik dari masing - masing penggumpal lateks yang digunakan sebagaimana tabel 5. 
Tabel 5. Jenis Penggumpal Yang digunakan

\begin{tabular}{clccc}
\hline No & \multicolumn{1}{c}{ Jenis Penggumpal } & $\mathrm{pH}$ & Lama Pembekuan (Menit) & Rendemen(\%) \\
\hline 1. & Larutan Asam Formiat 2 \% & 2,6 & 24,00 & 53,89 \\
\hline 2. & Larutan TSP TSP 2 \% & 3,6 & 1.740 & 33,10 \\
\hline 3. & Asap Cair Cangkang Sawit 2 \% & 3,0 & 72,50 & 38,71 \\
\hline 4. & Asap Cair Cangkang Sawit 6 \% & 2,8 & 62,00 & 45,55 \\
\hline $\begin{array}{l}\text { Asap Cair Cangkang Sawit 10 } \\
\text { 5. }\end{array}$ & 2,8 & 49,50 & 50,79 \\
\hline $\begin{array}{l}\text { Asap Cair Cangkang Sawit 14 } \\
\text { 6. }\end{array}$ & 2,7 & 24,50 & 58,44 \\
\hline
\end{tabular}

\section{a. pH}

Pada tabel 5 diperoleh hasil bahwa asap cair $2 \%$ memiliki pH paling tinggi yaitu 3,0 sementara asap cair $14 \%$ memiliki $\mathrm{pH}$ paling rendah yaitu 2,7. Ini menunjukkan bahwa semakin tinggi konsentrasi asap cair maka pH asap cair semakin kecil atau semakin asam. Hal ini disebabkan karena asap cair $14 \%$ mengandung asam asetat lebih banyak dari pada asap cair $10 \%, 6 \%$ dan $2 \%$ sebagaimana Tabel 5. Sementara larutan TSP $2 \%$ memiliki pH 3,6, ini disebabkan karena adanya kandungan Kalsium dan Phospat yang cenderung bersifat basa sehingga $\mathrm{pH}$ menjadi agak tinggi.

Pada tabel 5, juga diperoleh hasil bahwa larutan asam formiat $2 \%$ memiliki pH paling kecil dibandingkan semua penggumpal yang digunakan yaitu 2,6. Ini disebabkan karena Asam formiat merupakan asam terkuat dari asam - asam karboksilat lainnya (Imama, 2013).

\section{b. Lama Pembekuan (Waktu Penggumpalan)}

Tabel. 5 , diperoleh hasil bahwa asap cair $14 \%$ mampu menggumpalkan lateks selama 24,50 menit, sementara asap cair $2 \%$ mampu menggumpalkan lateks selama 72,50 menit. Hal ini menunjukkan bahwa semakin tinggi konsentrasi asap cair maka waktu penggumpalan semakin cepat. Hal ini disebabkan karena semakin tinggi konsentrasi asap cair maka derajat keasaman atau $\mathrm{pH}$ nya semakin tinggi sebagaimana yang ditunjukkan Tabel 5 , sehingga kemampuan untuk menurunkan pH lateks mendekati titik isoelektrinya yaitu 4,5 - 4,7 ( Zuhrah, 2006 dalam Maryanti dan Rachmad Edison, 2016 ) dan menggumpal semakin cepat. Menurut Johansyah (2011), penggunaan asap cair sebagai koagulan lateks dengan konsentrasi berbeda sangat berpengaruh terhadap waktu penggumpalan lateks dan dapat menghasilkan gumpalan lateks sesuai Standar Indonesian Rubber (SIR). Kemampuan asap cair dalam menggumpalkan lateks khususnya konsentrasi $14 \%$ tidak berbeda jauh dengan larutan asam formiat $2 \%$, ini dikarenakan adanya senyawa aktif yaitu asam asetat sebagaimana Tabel 5 . Asam asetat merupakan salah satu asam karboksilat paling sederhana, setelah asam formiat (Anonim, 2008) sehingga kemampuan untuk menggumpalkan lateks tidak jauh berbeda dengan asam formiat.

Penggumpalan lateks adalah suatu peristiwa perubahan fase sol menjadi gel dengan bantuan bahan penggumpal yang biasa disebut koagulan. Lateks akan menggumpal jika muatan listrik diturunkan (dehidratasi), $\mathrm{pH}$ lateks diturunkan (penambahan asam $\mathrm{H}+$ ) dan penambahan elektrolit (Abednego, 1981). Pada Tabel 5 juga diketahui bahwa larutan Asam Formiat $2 \%$ mampu menggumpalkan lateks dengan waktu yang paling cepat dibandingkan semua penggumpal yang digunakan yaitu 24,00 menit (lebih cepat 0,5 menit dibandingkan asap cair $14 \%$ ). Sementara larutan TSP $2 \%$ memerlukan waktu yang paling lama untuk menggumpalkan yaitu 1.720 menit. Asam formiat merupakan asam terkuat dari asam - asam karboksilat lainnya (Imama, 2013). Hal ini disebabkan karena pH dari larutan asam formiat 2 $\%$ yang cukup tinggi yaitu 2,6 sehingga dengan cepat mampu menurunkan $\mathrm{pH}$ lateks segar $(6,5)$ hingga menggumpal. TSP merupakan salah satu jenis pupuk yang mengandung Kalsium 
dan Phospat yang cukup tinggi sehingga jika ditambahkan ke dalam lateks akan membentuk senyawa kompleks yang tidak larut dalam air (Hidayoko dan Okta, 2014) hal inilah yang diduga menjadi penyebab lamanya pengumpalan.

\section{c. \% Rendemen}

Rendemen merupakan persentase perbandingan antara lateks yang telah beku dengan jumlah lateks sebelum dibekukan/digumpalkan. Pengukuran rendemen ditujukan untuk mengetahui keefisiensian 6 bahan penggumpal yang digunakan untuk membekukan lateks. Pada Tabel 5 diperoleh hasil bahwa asap cair $2 \%$ mampu menggumpalkan lateks dengan rendemen paling kecil yaitu 38,71\% sementara asap cair dengan konsentrasi $14 \%$ mampu menggumpalkan lateks rendemen yang paling tinggi yaitu 53,44 \%. Ini menunjukkan bahwa semakin besar konsentrasi asap cair maka rendemen semakin besar. Hal ini disebabkan karena semakin besar konsentrasi asap cair maka luas kontak antara lateks dan penggumpal yaitu asap cair semakin besar, sehingga lapisan selubung protein karet akan mudah dan cepat terpecah. Selain itu besar konsentrasi yang diberikan menyebabkan semakin menurunnya nilai pH lateks mendekati titik isoelektriknya. Menurut Ali dkk (2010), titik isoelektrik pada lateks sekitar 4,7. Pada kondisi tersebut banyak partikel-partikel koloid pada lateks tidak stabil akibat kontak dengan koagulan yang menyebabkan struktur protein pada lateks terganggu. Ketika struktur protein terganggu maka fungsi struktur protein sebagai pelindung lateks akan menurun sampai terjadi pemecahan lapisan pelindung (Ali dkk, 2015). Semakin banyak selubung protein karet yang pecah maka akan semakin cepat proses terbentuknya gumpalan karet dan rendemen semakin besar.

Pada tabel 5 juga diperoleh hasil bahwa larutan TSP $2 \%$ mampu menggumpalkan lateks dengan rendemen sebesar 33,11 \%. Nilai ini merupakan nilai terkecil dibandingkan dengan penggumpal lateks yang lain, hal ini disebabkan karena senyawa - senyawa penggangu yang ada pada larutan TSP $2 \%$ seperti kalsium dan phospat sehingga menghambat proses penggumpalan. Sementara penggumpal larutan asam formiat $2 \%$ memiliki rendemen sebesar 53,89 \%. Nilai ini lebih tinggi dibandingkan nilai - nilai rendemen yang diperoleh dari semua penggumpal yang digunakan. Hal ini disebabkan karena asam formiat merupakan asam terkuat dari asam - asam karboksilat lainnya (Imama, 2013). pH 2,6 yang dimiliki oleh larutan asam formiat $2 \%$ juga menyebabkan kemampuannya dalam menggumpalkan menjadi lebih besar.

\section{KESIMPULAN}

Dari hasil penelitian dapat disimpulkan bahwa asap cair yang diperoleh pada kisaran suhu $300-400{ }^{\circ} \mathrm{C}$ merupakan asap cair yang paling optimal yang dapat digunakan sebagai bahan penggumpal lateks. Pada kisaran suhu $300-400^{\circ} \mathrm{C}, \mathrm{pH}$ yang dihasilkan sebesar 2,8 , kadar asam asetat sebesar 50,54 \% dan fenol sebesar 32,59 \%. Kelebihan asap cair dibandingkan asam formiat sebagai penggumpal lateks adalah asap cair mengandung senyawa asam asetat, senyawa fenol serta senyawa lainnya yang berpengaruh terhadap $\mathrm{pH}$ dan anti bakteri serta ramah lingkungan. asam formiat hanya memberikan $\mathrm{pH}$ yang rendah dan waktu penggumpalan lateks yang cepat serta tidak ramah lingkungan.

\section{DAFTAR PUSTAKA}

Ali, F., S. Arta, dan F. Ahmad, 2010. Koagulasi lateks dengan ekstrak gadung (Dioscorea hispida Dennts). Jurnal Teknik Kimia 17(3): 8 - 16.

Ali, F., W. N, Astuti, dan N. Chairani. 2015. Pengaruh volume koagulan, waktu kontak dan temperatur pada koagulasi lateks dari kayu karet dan kulit kayu karet. Jurnal Teknik Kimia 21(3): 27 - 35. 
Darmadji, P. 1996. Aktivitas Antibakteri Asap Cair dari Bermacam - macam Limbah

Daun, H, 1979. Interaction Of Wood Smoke Component and Foods, Food Technolgy.33: 66 71.

Fauziati, Ella R, Prasetyo I, Fitriani \& Gasi, 2011. "Pengembangan Wood Vinegar dari Limbah kelapa sawit Sebagai Antiseptik Pembersih Tangan Baristand Industri Samarinda.

Fauziati, Sampepana Eldha, Rinaldi Adhitya, 2014. Optimalisasi Proses Pemurnian Asap Cair dari Cangkang Sawit. Balai Riset dan Standardisasi Industri Samarinda.

Gani Abdul, 2013, Komponen Kimia Asap Cair Hasil Pirolisis Limbah Padat Kelapa Sawit.

Jurnal Rekayasa Kimia dan Lingkungan Volume 9 Nomor 3 Halaman 109 - 116. ISSN 1412 5064.

Girald, J.P ,1992,Smoking dalam J.P. Girald :Technology Of Meat and Meat Product, Elis Horwood.New York .pp: 165 - 201.

Imama, N. 2013. Asam Formiat. https://www.ilmukimia.org/2013/11/asam - semut.html. diakses tgl. 18 Okt 2017.

Maga , JA. 1987 Smoke in Food Processing , CRC Press, Inc, Boca Raton, Florida.

Marpaung ,DS ,2009,Pemanfaatan Limbah Pabrik Kelapa Sawit Sebagai Pembangkit Listrik http// Deddy Suhendra Marpaung Blok.spot .com Oktober,2009.

Novita A. R , 2011. Aktivitas Asap Cair Tempurung Kelapa sebagai Desinfektan.

P Girald, J.P ,1992, Technology Of Meat and Meat Product.

Pranata, 2008. Asap Cair Sebagai Pengawet Makanan Siap Saji.

Rahmi, N dan Pudjilestari T. 2008 , Aktivitas Antibakteri Dari Cuka Kayu Pohon Akasia, Karet dan Galam . Warta Balai Industri Banjar Baru . Vol XXIIINo 2 ,Hal 21 - 25 , Balai Riset dan Stndrdisasi Industri Banjar Baru .

Ratnawati dan Singgih hartanto, 2010, Pengaruh Suhu Pirolisis Cangkang Sawit Terhadap Kuantitas dan Kualitas Asap Cair .Jurnal Sainsmateri Indonesia Indonesian Journal Ofmaterials Science Vol 12, No 1Oktober 2010, Hal :7 - 1 ,Issn: 1411 - 1098 .

Tahir I , 1992 , Pengambilan Asap Cair Secara Destilasi Kering Pada Proses Pembuatan Carbon Aktif Dari Tempurung Kelapa, Skripsi FMIPA UGM ,Yogyakarta .

Tilman ,D, 1981, Wood Combution : Principles, Processes and Economics Academics PressInc,New York, hal 74 - 93

Tranggono, dkk , 1987, Adsorbsi Senyawa KomponenAsap Cair Dengan Zeolit. Makalah disampaikan pada Seminar Nasional Pangan dan Gizi dan Konggres PAPTI.

Sutin, 2008, Pembuatan Asap Cair Dari Tempurung dan Sabut Kelapa Secara Pirolisis Serta Fraksinasinya Dengan Ekstraksi, Institut Pertanian Bogor. 